\title{
Preventive Control of Pythium Root Dysfunction in Creeping Bentgrass Putting Greens and Sensitivity of Pythium volutum to Fungicides
}

\author{
J. P. Kerns, M. D. Soika, and L. P. Tredway, Department of Plant Pathology, North Carolina State University, \\ Raleigh 27695
}

\begin{abstract}
Kerns, J. P., Soika, M. D., and Tredway, L. P. 2009. Preventive control of Pythium root dysfunction in creeping bentgrass putting greens and sensitivity of Pythium volutum to fungicides. Plant Dis. 93:1275-1280.

Pythium root dysfunction (PRD), caused by Pythium volutum, has been observed on golf course putting greens established with creeping bentgrass in the southeastern United States since 2002. To evaluate preventative strategies for management of this disease, a 3-year field experiment was conducted in Pinehurst, NC on a 'G-2' creeping bentgrass putting green. Fungicide treatments were applied twice in the fall (September and October) and three times in the spring (March, April, and May) in each of the 3 years. Applications of pyraclostrobin provided superior preventative control compared with the other fungicides tested. Azoxystrobin and cyazofamid provided moderate control of PRD in two of three seasons. Experiments were conducted to determine whether the disease suppression provided by pyraclostrobin was due to fungicidal activity or physiological effects on the host. In vitro sensitivity to pyraclostrobin, azoxystrobin, fluoxastrobin, cyazofamid, mefenoxam, propamocarb, and fluopicolide was determined for $11 P$. volutum isolates and $1 P$. aphanidermatum isolate. Isolates of $P$. volutum were most sensitive to pyraclostrobin $\left(50 \%\right.$ effective concentration $\left[\mathrm{EC}_{50}\right]$ value $\left.=0.005\right)$, cyazofamid $\left(\mathrm{EC}_{50}=0.004\right)$, and fluoxastrobin $\left(\mathrm{EC}_{50}=0.010\right)$, followed by azoxystrobin $\left(\mathrm{EC}_{50}=0.052\right)$, and mefenoxam $\left(\mathrm{EC}_{50}=0.139\right)$. P. volutum isolates were not sensitive to fluopicolide or propamocarb. Applications of pyraclostrobin did not increase the foliar growth rate or visual quality of creeping bentgrass in growth-chamber experiments. This work demonstrates that fall and spring applications of pyraclostrobin, azoxystrobin, and cyazofamid suppress the expression of PRD symptoms during summer and that field efficacy is related to the sensitivity of $P$. volutum to these fungicides.
\end{abstract}

Creeping bentgrass (Agrostis stolonifera L.) is widely planted in the southeastern (SE) United States on golf course putting greens. This cool-season turfgrass is ideal for golf course putting greens because it tolerates extremely close mowing and produces a uniform playing surface (24). However, most of the SE United States is in the transition zone for cool- and warmseason turfgrasses, and the hot, humid summers often result in reduced turf vigor and increased susceptibility to diseases. In addition, the United States Golf Association (USGA) recommends a sand-based rootzone for putting green construction, which has low nutrient- and water-holding capacities (24). Although these construction practices may reduce the development of fungal diseases that are encouraged by wet soil conditions, they may also enhance other diseases that are encouraged by physiological stress, such as Pythium root dysfunction (PRD).

Corresponding author: J. P. Kerns

E-mail: jpk@plantpath.wisc.edu

Accepted for publication 20 July 2009.

doi:10.1094/PDIS-93-12-1275

(C) 2009 The American Phytopathological Society
Pythium root dysfunction of creeping bentgrass was first described by Hodges and Coleman in 1985 (5). They observed that newly established, high-sand-content ( $>60 \%$ sand) putting greens were wilting in irregular patters that eventually progressed to foliar decline. Pythium aristosporum and $P$. arrhenomanes were consistently isolated from diseased roots, and these species were highly virulent toward the secondary roots of creeping bentgrass. In 1999, Feng and Dernoeden (4) identified eight Pythium spp. (P. aristosporum, $P$. aphanidermatum, $P$. catenulatum, $P$. graminicola, $P$. torulosum, $P$. vanterpoolii, $P$. volutum, and $P$. ultimum var. ultimum) in a collection of 28 isolates from 109 putting green samples exhibiting symptoms of PRD. Based on the frequency of isolation and pathogenicity experiments, it was concluded that $P$. aristosporum was the most important causal agent of PRD in the mid-Atlantic region of the United States. In 2007, Kerns and Tredway (9) confirmed that $P$. volutum was the cause of $\mathrm{PRD}$ in samples from North Carolina, South Carolina, Georgia, and Virginia.

In North Carolina, symptoms of PRD typically develop during the summer months, when creeping bentgrass is subjected to heat and drought stress. Symptoms initially develop as wilt or chlorosis, then progress to foliar decline, which is likely due to rapid dieback of roots. In growth-chamber experiments, symptoms were induced when creeping bentgrass was exposed to day and night temperatures of 32 and $26^{\circ} \mathrm{C}$, respectively (9). However, the majority of hyphal growth and oospore production is observed in infected roots in the fall, winter, and spring, when creeping bentgrass roots are most actively growing. Based on our current understanding of PRD epidemiology, fungicide applications during the time of pathogen activity may provide more effective disease control.

Since its description in 1985 , very little research has been conducted to identify effective control strategies for PRD. Hodges (6) reported that the contact and systemic fungicides specific for Pythium spp. control were not effective; therefore, golf course superintendents were forced to reestablish the diseased areas once air and soil temperatures became conducive for creeping bentgrass growth. Hodges (6) indicated that the primary problem was the inability to move fungicides into the rootzone. The only other research addressing PRD prior to 2004 was Feng and Dernoeden's (4); however, no managementoriented experiments were reported.

In North Carolina, Tredway and Butler $(21,22)$ tested fungicides for early and late curative control of PRD in an 'A-1' creeping bentgrass putting green. All treatments and programs that included pyraclostrobin were nearly free of disease symptoms during late June and early July. Suppression of disease symptoms were not observed with any of the standard Pythium spp. fungicides, which included mefenoxam, fosetyl$\mathrm{Al}$, propamocarb, and ethazole. As the heat and drought stress increased through late July and early August, no treatments or programs significantly suppressed PRD symptoms compared with the untreated controls. Research was needed to determine whether preventative applications, when the pathogen is actively infecting roots, are more effective for management of PRD.

Pyraclostrobin belongs to the strobilurin group of the class of fungicides known as the quinone outside inhibitors (QoIs). The QoIs are a relatively new class of fungicides that are used on a broad range of crops for suppression of all major fungal pathogen groups, as well as oomycetes $(20,25)$. These fungicides inhibit mitochondrial respiration by binding to the Qo 
center of cytochrome $b$, thereby blocking the electron transport chain. As a result, the production of ATP is terminated and fungal growth is inhibited (2). Because of this biochemical mode of action, the QoIs are most effective as a prophylactic treatment. Preventative applications of azoxystrobin provided $100 \%$ control of grapevine downy mildew (Plasmopara viticola), yet curative applications did not significantly reduce downy mildew incidence when compared with the untreated controls (28). Three studies reported similar results when comparing the preventative and curative activity of azoxystrobin in other pathosystems $(1,12,17,18)$. Studies examining the physical mode of action of other QoIs (pyraclostrobin and trifloxystrobin) have documented excellent preventative activity against Cercospora beticola but these fungicides have limited curative activity against this fungus (8).

In addition to the direct effects of the QoIs, some appear to have an affect on plant physiological processes. A significant increase in yield and grain quality resulting from applications of QoI fungicides has been documented in wheat and barley (2). Equivalent levels of disease control were provided by DMI-based programs when compared with QoI-based programs, yet QoI-based programs provided higher yields that could not be explained by enhanced disease control. This phenomenon was coined the "QoI greening effect" because it is associated with an increase in green leaf area late into the growing season, which in turn increases grain yield (2). Two studies have shown that a variety of physiological processes are directly affected by QoIs, which resulted in more biomass and enhanced yield $(5,16)$. QoIs are commonly used in turfgrass disease management programs, yet little is known about the effects of QoI applications on turfgrass growth and physiology.

Resistance to the QoI fungicides in the field has been documented with several turfgrass pathogens. California populations of Colletotrichum cereale, the causal agent of turfgrass anthracnose, demonstrated in vitro and in vivo resistance to azox-

Table 1. Treatments, rates, and post-application treatment for preventative control of Pythium root dysfunction in 2004 through 2007

\begin{tabular}{lcc}
\hline Fungicide & $\begin{array}{c}\text { Rate (product } \\
\left.\text { at } \mathbf{g} \text { or } \mathbf{~ m l ~ m}^{-2}\right)^{\mathbf{y}}\end{array}$ & $\begin{array}{c}\text { Watered } \\
\mathbf{i n}^{\mathbf{z}}\end{array}$ \\
\hline Control & $\ldots$ & - \\
Menfenoxam & $0.31 \mathrm{ml}$ & + \\
Propamocarb & $2.44 \mathrm{~g}$ & + \\
Fosetyl-Al & $1.3 \mathrm{ml}$ & - \\
Ethazole & $1.22 \mathrm{~g}$ & + \\
Azoxystrobin & $0.12 \mathrm{~g}$ & + \\
Pyraclostrobin & $0.28 \mathrm{~g}$ & + \\
Trifloxystrobin & $0.076 \mathrm{~g}$ & + \\
Cyazofamid & $288 \mathrm{ml}$ & + \\
\hline
\end{tabular}

y Treatments were applied in $\mathrm{H}_{2} \mathrm{O}$ at $81.5 \mathrm{ml} \mathrm{m}^{-2}$.

${ }^{\mathrm{z}}$ Treatments did (+) or did not $(-)$ receive 6.4 $\mathrm{ml}$ of irrigation immediately after application. ystrobin, trifloxystrobin, and pyraclostrobin (27). Populations of Pyricularia grisea, the gray leaf spot pathogen, displayed resistance to azoxystrobin and trifloxystrobin in field experiments and in in vitro assays $(11,26)$. Field resistance to azoxystrobin has been documented in populations of Pythium aphanidermatum as well (2). Determining the sensitivity of $P$. volutum to different active ingredients may help support the results of previous and current field research. Fungicide sensitivity data will also provide a baseline for future monitoring if fungicide resistance develops in $P$. volutum populations.

To improve the management of PRD, research was needed to determine the basis of activity of pyraclostrobin and to evaluate fungicides for preventative control of PRD. The specific objectives of this study were to (i) evaluate fungicides for preventative control of PRD in field experiments, (ii) determine the in vitro sensitivity of $P$. volutum to fungicides, and (iii) evaluate the effects of pyraclostrobin applications on creeping bentgrass foliar growth rate.

\section{MATERIALS AND METHODS}

Preventative control of PRD. A 3-year field experiment was conducted at the Pinehurst Golf Resort in Pinehurst, NC on a ' $\mathrm{G}-2$ ' creeping bentgrass putting green that was severely affected with PRD. Isolations from the affected area revealed that $P$. volutum was the causal agent of PRD in this location. The putting green was constructed in 1993 according to USGA specifications (24) with a rootzone mix of $85 \%$ sand and $15 \%$ sphagnum peat moss by volume. In 2005, the site was fertilized with nitrogen at $171 \mathrm{~kg} \mathrm{ha}^{-1}$ and was mowed daily at $3.2 \mathrm{~mm}$ throughout the year. In 2006 and 2007, the putting green received $195 \mathrm{~kg} \mathrm{ha}^{-1}$ year $^{-1}$ and was mowed daily at $3.2 \mathrm{~mm}$ during the fall and spring and at $3.5 \mathrm{~mm}$ during the summer months. The study site was irrigated as needed to prevent drought stress.

Fungicide treatments and application dates are shown in Table 1 and were initiated in September 2004 and continued in the fall of 2005 and 2006. Fall applications were initiated when soil temperatures declined to $24^{\circ} \mathrm{C}$ and spring applications were initiated when soil temperatures increased to $12^{\circ} \mathrm{C}$ (Table 1). Treatments were applied with a $\mathrm{CO}_{2}$-powered boom sprayer at $276 \mathrm{kPa}$ using flat fan nozzles (TeeJet 8004; R\&D Sprayers, Opelousas, LA) calibrated to deliver $\mathrm{H}_{2} \mathrm{O}$ at $81.5 \mathrm{ml}$ $\mathrm{m}^{-2}$. All treatments except fosetyl-Al were watered in with $64 \mathrm{~mm}$ of $\mathrm{H}_{2} \mathrm{O}$ immediately after application. Plots were $4.6 \mathrm{~m}^{2}$ and were arranged in a randomized complete block design with four replications. Treatments were applied to the same experimental area in all 3 years.

Disease severity was evaluated biweekly during the summer months using a modified Horsfall-Barratt (HB) scale (11 =
$100 \% 6=50$ to $75 \%$, and $0=0 \%$ ) (3). The scale data were converted to the geometric mean of the percentage range corresponding to the scale number (3) in order to calculate area under the disease progress curve (AUDPC) values (19). Three ratings were used to calculate AUDPC values. Turf quality was assessed visually by estimating the overall uniformity, density, and color within each plot before every fungicide application and during each disease severity rating. Turfgrass quality was quantified using a 1-to-9 scale $(9=$ best, $5=$ minimally acceptable, and $1=$ bare ground). AUDPC values were subjected to analysis of variance (ANOVA; PROC GLM) and mean separations using the Waller-Duncan $k$-ratio $t$ test $(k=100)$ in SAS (version 8.02; SAS Institute, Cary, NC).

In vitro sensitivity of $P$. volutum to fungicides. The sensitivity of $11 P$. volutum isolates and one $P$. aphanidermatum isolate to pyraclostrobin, azoxystrobin, mefenoxam, cyazofamid, propamocarb, fluopicolide, and fluoxastrobin was determined in mycelial growth assays. $P$ aphanidermatum was included in the sensitivity assay as a standard for comparison. Fluopicolide and fluoxastrobin were not included in field experiments because they were not available for testing in 2005, when this study was initiated. Hyphal plugs $(4 \mathrm{~mm})$ from the edge of actively growing colonies on clarified V8 juice agar (14) were placed in the center of petri dishes containing potato dextrose agar (PDA) amended with six concentrations $(0,0.0001,0.001,0.01,0.1,1$, and 10 $\mu \mathrm{g} / \mathrm{ml}$ ) of commercially formulated pyraclostrobin (Insignia 20WG; BASF), azoxystrobin (Heritage 50WDG, Syngenta Professional Products); mefenoxam (Subdue MAXX 2ME; Syngenta Professional Products), propamocarb (Banol 6SL; Bayer Environmental Science), fluoxastrobin (Disarm 480SC; Arysta Life Science), or cyazofamid (Segway 3.33SC; FMC). Technical-grade fluopicolide was used because of the lack of commercially formulated product for the turf and ornamentals market and was provided by Valent Professional Products. Salicylhydroxamic acid (SHAM, $100 \mu \mathrm{g} / \mathrm{ml}$ ) was added to all pyraclostrobin, fluoxastrobin, and azoxystrobin concentrations to inhibit the alternative oxidase pathway, and a PDA + SHAM control was also included. Fungicide and SHAM solutions were added to autoclaved PDA that was cooled to approximately $55^{\circ} \mathrm{C}$.

$P$. volutum cultures were incubated in the dark at $23^{\circ} \mathrm{C}$ for 3 days. Cultures of $P$. aphanidermatum were incubated for $24 \mathrm{~h}$ due its rapid growth rate. The diameter of each colony was measured in two perpendicular directions and the mean diameter was adjusted by subtracting the diameter of the hyphal plug. Relative growth $(\mathrm{RG}=$ [the mean adjusted colony diameter on 
fungicide-amended medium/the mean adjusted colony diameter on nonamended medium]) was determined for each isolate, fungicide, and fungicide concentration. Each fungicide-isolate combination was replicated three times and the experiment was repeated twice.

The $50 \%$ effective concentration $\left(\mathrm{EC}_{50}\right)$ values were estimated by linear regression (PROC REG in SAS, version 8.02) of the probit-transformed relative inhibition value (RI = $1-\mathrm{RG}$ ) on $\log _{10}$-transformed fungicide concentration $(13,15)$. The $\mathrm{EC}_{50}$ values for each $P$. volutum isolate were subjected to an ANOVA (PROC GLM in SAS, version 8.02) and mean separations using the Waller-Duncan $k$-ratio $t$ test $(k=100)$.

Impact of pyraclostrobin on creeping bentgrass growth. Cone-tainers ( 3.8 by 20 $\mathrm{cm}$ ) containing sand meeting USGA specifications (24) (BB 205; Golf Agronomics Inc., Rockingham, NC) were seeded with Penn-A-1 creeping bentgrass $\left(9.7 \mathrm{~g} \mathrm{~m}^{-1}\right)$. The cone-tainers were placed in a greenhouse at 26 and $22^{\circ} \mathrm{C}$ (day and night, respectively, in 12-h cycles) and were misted twice daily to encourage rapid germination. Following germination, the turf was maintained in the greenhouse by irrigating twice daily with a complete nutrient solution containing nitrogen at $106.23 \mathrm{~mol} \mathrm{~m}^{-3}$, phosphorus at $10.41 \mathrm{~mol} \mathrm{~m}^{-3}$, and potassium at $111.03 \mathrm{~mol} \mathrm{~m}^{-3}$. The turf was trimmed weekly with scissors to a height of $1.27 \mathrm{~cm}$.

Six weeks after seeding, cone-tainers were transferred to a growth chamber with 12-h cycles of day and night at 24 and $16^{\circ} \mathrm{C}$, respectively. Treatments were arranged in a completely random factorial design with six replications. Nitrogen treatments $\left(0,50,100\right.$, or $\left.200 \mathrm{~mol} \mathrm{~m}^{-3}\right)$ were applied daily in a complete nutrient solution that contained phosphorus at $10.41 \mathrm{~mol} \mathrm{~m}^{-3}$ and potassium at 111.03 mol m$~^{-3}$ for 4 weeks. Four weeks after initiation of the nitrogen treatments, pyraclostrobin was applied at $0,140,280,560$, $1,120,2,240$, or $4,480 \mathrm{~g} \mathrm{ha}^{-1}$. Pyraclostrobin treatments were applied once using a spray chamber at 40 psi using a flat-fan nozzle (Tee Jet 8004 ; R\&D Sprayers) calibrated to deliver 18.71 liters $\mathrm{ha}^{-1}$. The entire experiment was repeated twice.

The cone-tainers were cut with scissors to a height of $1.27 \mathrm{~cm}$ after treatment with pyraclostrobin and returned to the growth chambers for an additional 2 weeks, at which time foliar growth was assessed by removing tissue to a height of $1.27 \mathrm{~cm}$ with scissors. Clippings were dried at $60^{\circ} \mathrm{C}$ for 3 days and weighed to assess foliar growth rate. A total of three clipping harvests were collected per experiment. Turf quality was assessed visually by estimating the overall uniformity, density, and color within each cone-tainer every 2 weeks as well. Turfgrass quality was quantified using a 1-to- 9 scale $(9=$ best, $5=$ minimally acceptable, and $1=$ bare ground).
Statistical analyses were performed in SAS, version 8.02. An ANOVA was performed using PROC GLM to estimate the effects of experiment, nitrogen rate, pyraclostrobin rate, and interaction terms on clipping yield and turf quality. The WallerDuncan $k$-ratio $t$ test $(k=100)$ was used for separation of means to compare nitrogen and pyraclostrobin rate effects.

\section{RESULTS}

Preventative control of PRD. In 2005, 2006, and 2007, foliar symptoms were not

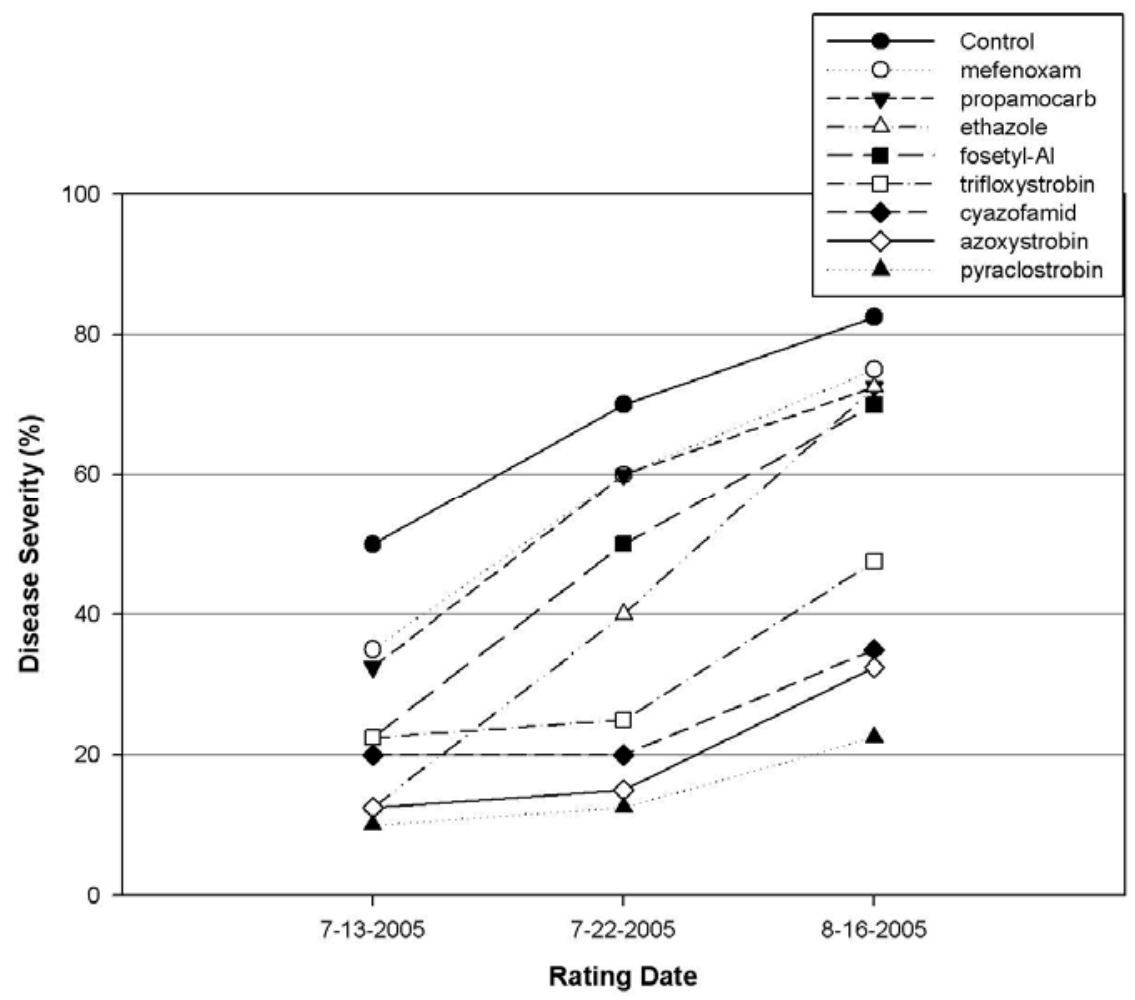

Fig. 1. Pythium root dysfunction severity in response to preventative fungicide applications in Pinehurst, NC in 2005. Treatments were applied on 9-22-04, 10-20-04, 3-29-05, 4-19-05, and 5-26-05. Disease severity was evaluated using a modified Horsfall-Barrett scale $(0=0 \%, 5=50$ to $75 \%$, and 11 $=100 \%$ ) based on foliar tissue exhibiting decline.

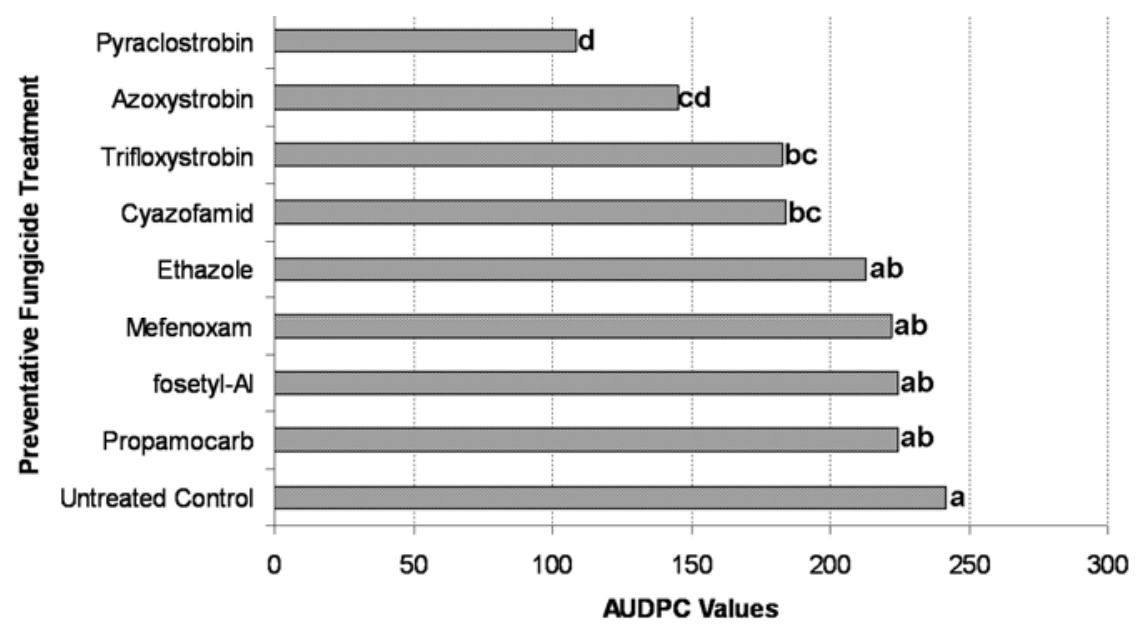

Fig. 2. Area under the disease progress curve values (AUDPC) in response to preventative fungicide applications in 2005. Treatments were applied on 9-22-04, 10-20-04, 3-29-05, 4-19-05, and 5-26-05. AUDPC values were calculated from disease severity data collected three times on a weekly interval. Bars followed by the same letter are not significantly different according to Waller-Duncan $k$-ratio $t$ test $(k=100)$. 


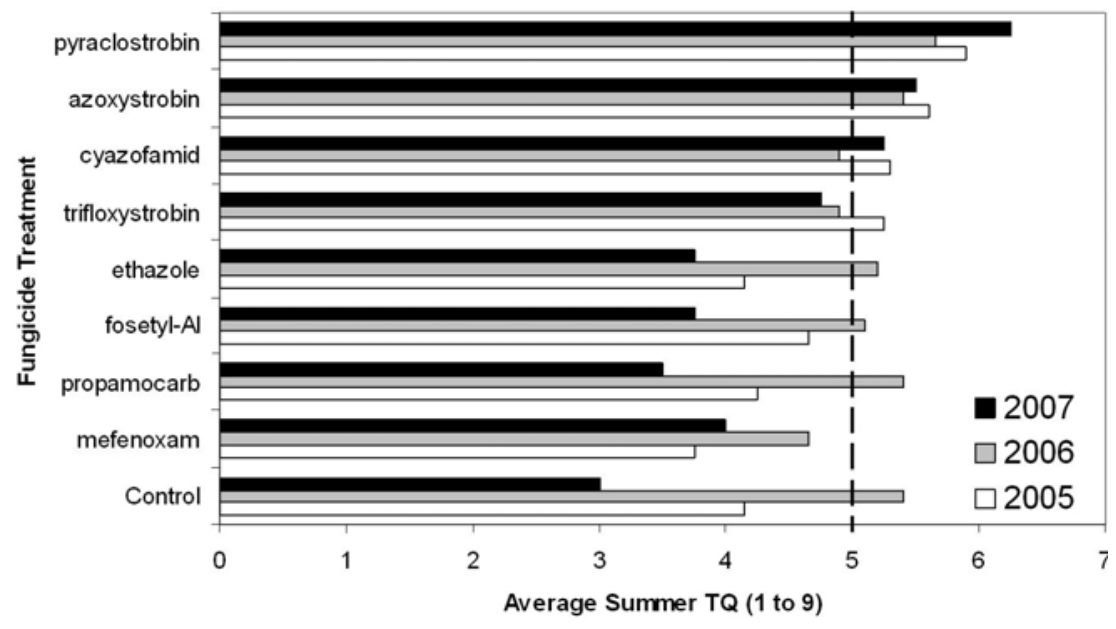

Fig. 3. Impact of preventative fungicide applications on turfgrass quality in 2005, 2006, and 2007. Turf quality was visually estimated on a scale of 1 to $9(1=$ bare ground $5=$ minimally acceptable, and $9=$ best). Bars represent the average of three turf quality rating dates. Dotted line represents acceptable turfgrass quality. Applications were made on 9-22-04, 10-20-04, 3-29-05, 4-19-05, 5-26-05, 9-4-05, 10-4-05, 3-15-06, 4-17-06, 5-17-06, 9-13-06, 10-12-06, 3-14-07, 4-12-07, and 5-16-07.

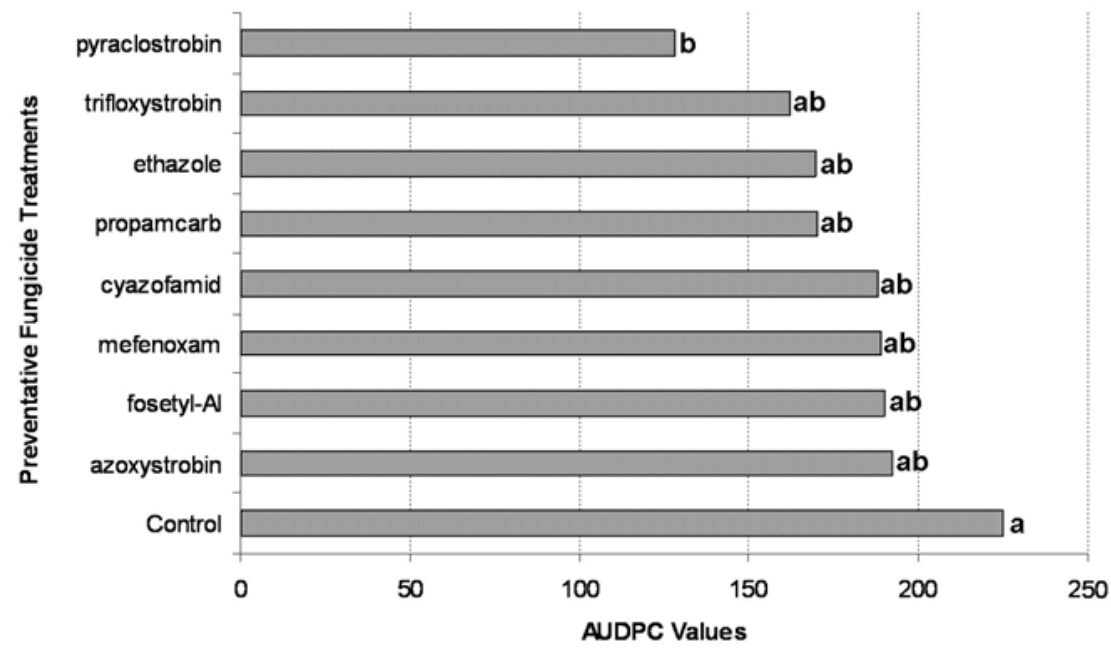

Fig. 4. Area under the disease progress curve values (AUDPC) in response to preventative fungicide applications in 2006 Treatments were applied on 9-4-05, 10-4-05, 3-15-06, 4-17-06, and 5-17-06.. AUDPC values were calculated from disease severity data collected three times on a weekly interval. Bars followed by the same letter are not significantly different according to Waller-Duncan $k$-ratio $t$ test $(k=100)$.

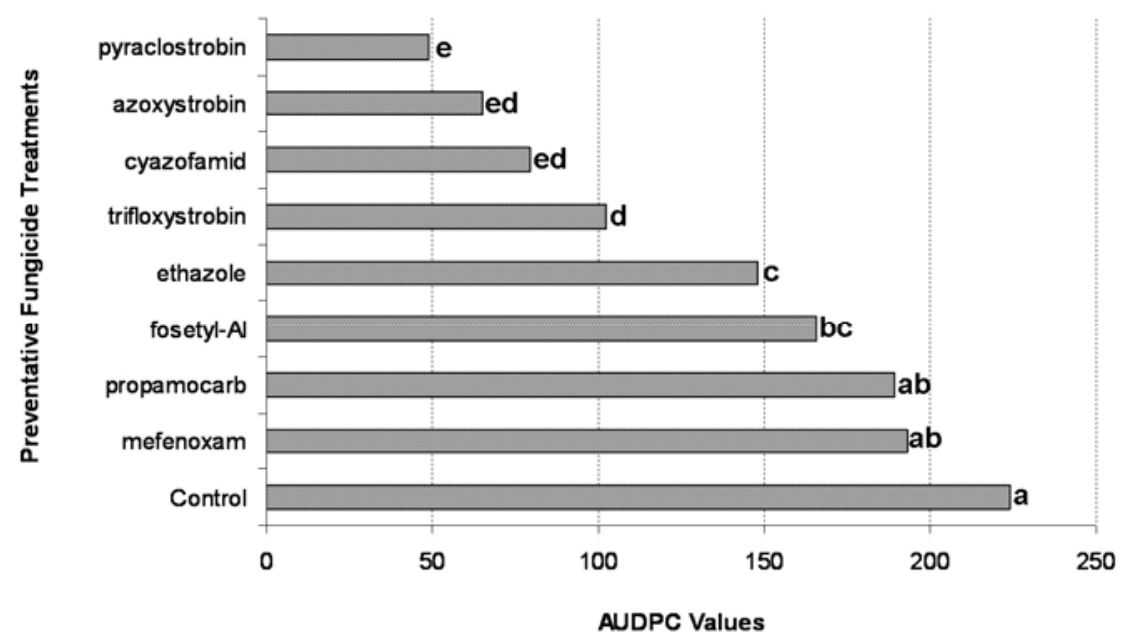

Fig. 5. Area under the disease progress curve values (AUDPC) in response to preventative fungicide applications in 2007. Applications for experiment 3 were made on 9-13-06, 10-12-06, 3-14-07, 4-12-07, and 5-1607 . AUDPC values were calculated from disease severity data collected three times on a weekly interval. Bars followed by the same letter are not significantly different according to Waller-Duncan $k$-ratio $t$ test $(k=100)$. able turf quality throughout the summer (Fig. 3). Symptoms of PRD developed in the beginning of July of 2006 as well but, in general, the symptoms were not as severe as in 2005 . In 2006, only pyraclostrobin provided suppression of disease symptoms when compared with the untreated control (Fig. 4). Differences in turf quality were minimal in 2006, with the untreated control demonstrating acceptable turf quality (Fig. 3). Symptom development occurred in early July 2007, yet the symptoms were minor at this time. However, by 9 August 2007, the symptoms had become severe in the untreated controls due to extremely hot, dry conditions. Fosetyl-Al-, ethazole-, trifloxystrobin-, cyazofamid-, azoxystrobin-, and pyraclostrobin-treated plots provided significant suppression of PRD compared with the untreated control (Fig. 5). However, acceptable turf quality was only observed in plots treated with pyraclostrobin, azoxystrobin, and cyazofamid (Fig. 3).

Sensitivity of $P$. volutum to fungicides. Variation of $\mathrm{EC}_{50}$ values between the two experiments was not significant and data from the two experiments were combined for analysis. $P$. volutum was highly sensitive to pyraclostrobin $\left(\mathrm{EC}_{50}=0.005\right)$, cyazofamid $\left(\mathrm{EC}_{50}=0.004\right)$, and fluoxystrobin $\left(E_{50}=0.010\right)$; moderately sensitive to azoxystrobin $\left(\mathrm{ED}_{50}=0.052\right)$; and the least sensitive to mefenoxam $\left(\mathrm{EC}_{50}=0.139\right)$ (Table 2). For the tested fungicide concentrations, a dose response to propamocarb or fluopicolide was not detected for most isolates of $P$. volutum (Table 2). In contrast, the single $P$. aphanidermatum isolate was most sensitive to pyraclostrobin, cyazofamid, and mefenoxam; moderately sensitive to azoxystrobin and fluopicolide; and the least sensitive to fluoxastrobin (Table 2). This particular isolate of $P$. aphanidermatum was not sensitive to propamocarb (Table 2).

Impact of pyraclostrobin on creeping bentgrass growth. ANOVA detected no significant differences among experiments; therefore, data presented are the average of the two experiments. Regardless of rate, pyraclostrobin did not significantly $(P>$ 0.05) impact creeping bentgrass foliar growth (Table 3 ). Increasing nitrogen rates caused an expected increase in clipping yield but a significant interaction between nitrogen and pyraclostrobin treatments was not detected (Table 3).

\section{DISCUSSION}

PRD was first described in 1985 (7), yet very little was known about the management of this disease prior to this work. Tredway and Butler $(21,22)$ had some success in controlling PRD curatively with fungicides but only 28 to 30 days of disease suppression was observed $(22,23)$. Although symptom expression primarily occurs during the summer months, recent epidemiological studies demonstrated that 
the PRD pathogen, $P$. volutum, infects creeping bentgrass roots when soil temperatures are between 12 and $24^{\circ} \mathrm{C}(10)$. In the current work, we demonstrate that applications of pyraclostrobin, azoxystrobin, and cyazofamid when soil temperatures are conducive for infection of creeping bentgrass roots by $P$. volutum provide summer-long suppression of PRD symptoms and maintain acceptable turf quality.

In 1985, Hodges (6) reported that contact and systemic fungicides specific for Pythium spp. control were ineffective for managing PRD. Similarly, standard $P y$ thium spp. fungicides such as mefenoxam, propamocarb, fosetyl-Al, and ethazole did not suppress PRD symptoms when applied on a preventative basis in our study or on a curative basis in trials conducted by Tredway and Butler $(21,22)$. The relatively low sensitivity of $P$. volutum to mefenoxam may explain the ineffectiveness of this active ingredient in field studies. $P$. volutum was also not sensitive to propamocarb in vitro, which corresponds with efficacy results in our field experiment. Sensitivities were not determined in this study for fosetyl-Al and ethazole but this information may help to explain the lack of PRD control provided by these fungicides in our trial. $P$. volutum was very sensitive in vitro to pyraclostrobin, azoxystrobin, and cyazofamid, which helps to explain why these chemicals were most effective in the field experiment. In vitro tests indicate that sensitivity to fluoxastrobin is comparable with pyraclostrobin but its effectiveness in field trials needs to be examined.

A single isolate of $P$. aphanidermatum was included in our sensitivity assay as a reference, because no sensitivity data existed for $P$. volutum. Comparing $\mathrm{EC}_{50}$ values between $P$. volutum and $P$. aphanidermatum is confounded by the fact that these two species infect different plant parts: $P$. aphanidermatum induces a foliar blight and $P$. volutum a root disease. There are many factors that determine the efficacy of a fungicide in the soil, such as solubility, sorption, and half-life. Thus, the only valid comparisons are among fungicides within a given pathogen. Furthermore, sensitivity data within a given species fail to fully explain field efficacy because of the many factors that influence fungicide efficacy in soil.

Creeping bentgrass growth was not impacted by applications of pyraclostrobin. In contrast, multiple studies have demonstrated enhanced growth and yield in cereal crops with applications of QoI fungicides which were not attributed to enhanced disease control $(2,5,12,14)$. This indicates that the suppression of PRD symptoms from applications of pyraclostrobin is primarily due to fungicidal properties and not enhanced foliar growth. However, we only examined foliar growth rate under optimal conditions in this particular experiment. The effects of pyraclostrobin applications on root depth and root mass and seed production remain unclear. Applications of pyraclostrobin have been shown to reduce stress and delay leaf senescence when exposed to heat or drought stress (12). An in-depth examination of the effects of pyraclostrobin applications on creeping bentgrass physiology under stress may help explain why pyraclostrobin was more effective against PRD than cyazofamid even though the in vitro sensitivities were similar.

PRD has become an important disease of creeping bentgrass in the SE United States (9). Prior to this work, golf course superintendents did not have an effective management strategy for PRD. Indeed, many superintendents have implemented a preventative control program based on results derived from these studies. As fungicides are increasingly used for control of PRD, fungicide resistance has the potential to develop. In order to combat this, we recommend that growers rotate between applications of pyraclostrobin, cyazofamid,

Table 2. In vitro sensitivity of Pythium volutum and P. aphanidermatum isolates to pyraclostrobin, azoxystrobin, cyazofamid, mefenoxam, propamocarb, fluopicolide, and fluoxastrobin

\begin{tabular}{|c|c|c|c|c|c|c|c|}
\hline \multirow[b]{3}{*}{ Isolate } & \multicolumn{7}{|c|}{$\mathbf{E C}_{50}$ concentration $\left(\mu \mathrm{g} \mathrm{ml}^{-1}\right)$ for fungicide class and material used ${ }^{\mathrm{z}}$} \\
\hline & \multicolumn{3}{|c|}{ QoI } & \multirow{2}{*}{$\frac{\text { QiI }}{\text { Cyazofamid }}$} & \multirow{2}{*}{$\begin{array}{c}\text { Phenylamides } \\
\text { Mefenoxam } \\
\end{array}$} & \multirow{2}{*}{$\begin{array}{c}\text { Carbamate } \\
\text { Propamocarb }\end{array}$} & \multirow{2}{*}{$\frac{\text { U9-acylpicolide }}{\text { Fluopicolide }}$} \\
\hline & Azoxystrobin & Fluoxastrobin & Pyraclostrobin & & & & \\
\hline \multicolumn{8}{|l|}{ P. volutum } \\
\hline OC 1 & $0.061 \mathrm{a}$ & $0.004 \mathrm{~b}$ & $0.004 \mathrm{a}$ & $0.003 \mathrm{a}$ & $0.094 \mathrm{~b}$ & 1.46 & 3.78 \\
\hline OC 4 & $0.042 \mathrm{a}$ & $0.007 \mathrm{~b}$ & $0.004 \mathrm{a}$ & $0.005 \mathrm{a}$ & $0.125 \mathrm{~b}$ & $>10$ & $>10$ \\
\hline OC 6 & $0.042 \mathrm{a}$ & $0.005 \mathrm{~b}$ & $0.004 \mathrm{a}$ & $0.002 \mathrm{a}$ & $0.074 \mathrm{~b}$ & 2.3 & $>10$ \\
\hline OC 9 & $0.044 \mathrm{a}$ & $0.009 \mathrm{~b}$ & $0.005 \mathrm{a}$ & $0.003 \mathrm{a}$ & $0.053 \mathrm{~b}$ & $>10$ & $>10$ \\
\hline PRD 12 & $0.052 \mathrm{a}$ & $0.008 \mathrm{~b}$ & $0.005 \mathrm{a}$ & $0.004 \mathrm{a}$ & $0.108 \mathrm{~b}$ & $>10$ & $>10$ \\
\hline PRD 22 & $0.051 \mathrm{a}$ & $0.014 \mathrm{a}$ & $0.005 \mathrm{a}$ & $0.003 \mathrm{a}$ & $0.212 \mathrm{a}$ & $>10$ & $>10$ \\
\hline PRD 29 & $0.052 \mathrm{a}$ & $0.010 \mathrm{a}$ & $0.008 \mathrm{a}$ & $0.005 \mathrm{a}$ & $0.109 \mathrm{~b}$ & $>10$ & $>10$ \\
\hline PRD 39 & $0.063 \mathrm{a}$ & $0.015 \mathrm{a}$ & $0.006 \mathrm{a}$ & $0.005 \mathrm{a}$ & $0.298 \mathrm{a}$ & $>10$ & $>10$ \\
\hline PRD 48 & $0.041 \mathrm{a}$ & $0.012 \mathrm{a}$ & $0.005 \mathrm{a}$ & $0.008 \mathrm{a}$ & $0.104 \mathrm{~b}$ & $>10$ & $>10$ \\
\hline PRD 7 & $0.042 \mathrm{a}$ & $0.013 \mathrm{a}$ & $0.004 \mathrm{a}$ & $0.004 \mathrm{a}$ & $0.213 \mathrm{a}$ & $>10$ & $>10$ \\
\hline SV 8 & $0.053 \mathrm{a}$ & $0.012 \mathrm{a}$ & $0.005 \mathrm{a}$ & $0.004 \mathrm{a}$ & $0.136 \mathrm{~b}$ & 1.58 & $>10$ \\
\hline Mean & 0.05 & 0.010 & 0.005 & 0.004 & 0.139 & $>10$ & $>10$ \\
\hline P. aphanidermatum & 0.48 & 4.65 & 0.270 & 0.210 & 0.230 & $>10$ & 0.585 \\
\hline
\end{tabular}

${ }^{\mathrm{z}} \mathrm{EC}_{50}=50 \%$ effective concentration. Commercial formulations of fungicides were used except for fluopicolide. QoI $=$ quinone outside inhibitor. QiI $=$ quinone inside inhibitor. Values followed by the same lowercase letter within a column for the $P$. volutum isolates are not significantly different according to Waller-Duncan $k$-ratio $t$ test $(k=100)$.

Table 3. Creeping bentgrass foliar growth as affected by nitrogen rate and pyraclostrobin rate

\begin{tabular}{|c|c|c|c|c|c|c|c|c|c|c|}
\hline \multirow[b]{2}{*}{ Growth } & \multicolumn{6}{|c|}{ Pyraclostrobin rate $\left(\mathrm{g} \mathrm{ha}^{-1}\right)^{\mathrm{x}}$} & \multicolumn{4}{|c|}{ Nitrogen rate $\left(\mathrm{mol} \mathrm{m}^{-3}\right)^{\mathrm{y}}$} \\
\hline & $\mathbf{0}$ & 140 & 560 & 1,120 & 2,240 & 4,480 & $\mathbf{0}$ & 50 & 100 & 200 \\
\hline Rate $\left(m g \text { day }^{-1}\right)^{\mathrm{z}}$ & 4.9 & 5.1 & 4.7 & 4.2 & 5.8 & 5.1 & $1.7 \mathrm{a}$ & $4.9 \mathrm{~b}$ & $6.2 \mathrm{c}$ & $7.3 \mathrm{c}$ \\
\hline
\end{tabular}

${ }^{x}$ Pyraclostrobin treatments were applied once using a spray chamber at 40 psi using a flat-fan nozzle (TeeJet 8004; R\&D Sprayers, Opelousas, LA) calibrated to deliver 18.71 liters ha $^{-1}$. No significant differences $(P$ value $=0.12)$ were detected among pyraclostrobin rates with respect to creeping bentgrass foliar growth.

${ }^{\mathrm{y}}$ Nitrogen treatments were applied daily in a complete nutrient solution that contained phosphorus at $10.41 \mathrm{~mol} \mathrm{~m}^{-3}$ and potassium at $111.03 \mathrm{~mol} \mathrm{~m}{ }^{-3}$ for 4 weeks. Values followed by the same letter are not significantly different according to Waller-Duncan $k$-ratio $t$ test $(k=100)$.

${ }^{\mathrm{z}}$ Growth rate was assessed by cutting the turf with scissors to a height of $1.27 \mathrm{~cm}$ after treatment with pyraclostrobin and returning it to the growth chambers for an additional 2 weeks, at which time foliar growth was removed to a height of $1.27 \mathrm{~cm}$ with scissors. Clippings were dried at $60^{\circ} \mathrm{C}$ for 3 days and weighed to assess foliar growth rate. 
and a propamocarb-plus-fosetyl-Al tank mix. Fluoxastrobin has not been evaluated for control of PRD in the field, although in vitro data suggest that it may be an effective treatment. If fungicide resistance does develop, then the results from our sensitivity assays will provide a preliminary sensitivity distribution that can be used to monitor shifts in the $P$. volutum population towards fungicide resistance.

Our results demonstrate that effective preventative control of PRD can be achieved when fungicides are applied during temperatures that are favorable for $P$. volutum infection. Isolates of $P$. volutum are very sensitive to pyraclostrobin and moderately sensitive to cyazofamid and azoxystrobin. Preventative fungicide programs should be based upon these active ingredients. Applications of pyraclostrobin did not impact creeping bentgrass growth rates, yet further research is needed to determine the impact of QoI applications on other physiological processes in turfgrasses under stress.

\section{ACKNOWLEDGMENTS}

This research was supported by grants from the Center for Turfgrass Environmental Research and Education at North Carolina State University (NCSU) and the North Carolina Turfgrass Foundation. We thank M. Bunting, B. Ma, and J. A. Roberts for valuable technical assistance; J. L. Shurtleff and the NCSU Phytotron for providing additional technical assistance and growth chamber space; $\mathrm{T}$. Gannon for providing time to use the NCSU Weed Science spray chamber; P. Landschoot for the $P$. aphanidermatum isolate; H. D. Shew and D. M. Benson for their helpful reviews of this manuscript prior to submission; and a big thank you to Paul Jett and the entire staff at the Pinehurst Golf Resort \& Spa in Pinehurst, NC.

\section{LITERATURE CITED}

1. Anesiadis, T., Karaoglanidis, G. S., and Tzavella-Klonary, K. 2003. Protective, curative, and eradicant activity of the QoI fungicide azoxystrobin against Cercospora beticola and Erysiphe betae. J. Phytopathol. 151:647-651.

2. Bartlett, D. W., Clough, J. M., Godwin, J. R., Hall, A. A., Hamer, M., and Parr-Dobrzanski, B. 2002. The QoI fungicides. Pest Manage. Sci. 58:649-662.

3. Campbell, C. L., and Madden, L. V. 1990. Pages 113-118 in: Introduction to Plant Dis- ease Epidemiology, 3rd edition. John Wiley and Sons, Hoboken, NJ.

4. Feng, Y., and Dernoeden, P. H. 1999. Pythium species associated with root dysfunction of creeping bentgrass in Maryland. Plant Dis. 83:516-520.

5. Gerhard M., Habermeyer, J., and Zindernagel, V. 1999. The impact of strobilurins on plant vitality on winter wheat under field conditions. Pages 197-208 in: Modern Fungicides and Antifungal Compounds II. 12th Int. Reinhardsbrunn Symp. Friedrichroda, Thuringia, Germany. Intercept Ltd., Andover, UK.

6. Hodges, C. F. 1985. Pythium-induced root dysfunction of creeping bentgrass on high sand content greens. Golf Course Manage. SeptOct. 11-13.

7. Hodges, C. F., and Coleman, L. W. 1985. Pythium-induced root dysfunction of secondary roots of Agrostis palustris. Plant Dis. 69:336-340.

8. Karadimos, D. A., Karaoglanidis, G. S., and Tzavella-Klonary, K. 2005. Biological activity and physical mode of action the Qo inhibitor fungicides trifloxystrobin and pyraclostrobin against Cercospora beticola. Crop Prot. 24:2329.

9. Kerns, J. P., and Tredway, L. P. 2008. Pathogenicity of Pythium species associated with Pythium root dysfunction of creeping bentgrass and their impact on root growth and survival. Plant Dis.92:862-869.

10. Kerns, J. P., and Tredway, L. P. 2008. Influence of temperature on pathogenicity of Pythium volutum toward creeping bentgrass. Plant Dis. 92:1669-1673.

11. Kim, Y. S., Dixon, E. W., Vincelli, P., and Farman, M. L. 2003. Field resistance to QoI fungicides in Pyricularia grisea caused by mutations in the cytochrome $b$ gene. Phytopathology 93:891-900.

12. Kohle, H., Grossmann, K., Jabs, T., Gerhard, M., Kaiser, W., Glaab, J., Conrath, U., Seehaus, K., and Herms, S. 2002. Physiological effects of the strobilurin fungicide F 500 on plants. Pages 61-74 in: Modern Fungicides and Antifungal Compounds III. H. W. Dehne, ed. AgroConcept, Bonn, Germany.

13. Ma, Z., Felts, D., and Michailides, T. J. 2003. Resistance to azoxystrobin in Alternaria isolates from pistachio in California. Pestic. Biochem. Physiol. 77:66-74.

14. Martin, F. N. 1992. Pythium. Pages 39-49 in: Methods for Research on Soilborne Phytopathogenic Fungi. L. L. Singleton, ed. The American Phytopathological Society, St. Paul, MN.

15. Miller, G. L., Stevenson, K. L., and Burpee, L. L. 2002. Sensitivity of Sclerotinia homeocarpa isolates to propiconazole and impact on con- trol of dollar spot. Plant Dis. 86:1240-1246.

16. Oerke, E. C., Beck, C., and Dehne, H.-W. 2001. Physiological effects of strobilurins on wheat yield. (Abstr.) Phytopathology 91:S67.

17. Rebollar-Alviter, A., Madden, L. V., and Ellis, M. A. 2007. Pre-and post-infection activity of azoxystrobin, pyraclostrobin, mefenoxam, and phosphite against leather rot of strawberry, caused by Phytophthora cactorum. Plant Dis. 91:559-564.

18. Rebollar-Alviter, A., Madden, L. V., Jeffers, S. N., and Ellis, M. A. 2007. Baseline sensitivity to two $\mathrm{Q}_{\mathrm{O}} \mathrm{I}$ fungicides among isolates of Phytophthora cactorum that cause leather rot and crown rot on strawberry. Plant Dis. 91:16251637

19. Shaner G., and Finney, R. E. 1977. The effect of nitrogen fertilization on the expression of slow-mildewing resistance in Knox wheat. Phytopathology 67:1051-1056.

20. Stiles, C. M., Datnoff, L. E., and Cisar, J. L. 2005. Evaluation of fungicides for control of Pythium blight in overseeded turfgrasses using a simple field inoculation technique. Online. Plant Health Progress doi: 10.1094/PHP-20050330-01-RS.

21. Tredway, L. P., and Butler, E. L. 2004. Late curative control of an unknown root disease of creeping bentgrass putting greens. Online. Center for Turfgrass Environmental Research and Education.

22. Tredway, L. P., and Butler, E. L. 2004. Preventative control of an unknown root disease of creeping bentgrass putting greens. Online. Center for Turfgrass Environmental Research and Education.

23. Tredway, L. P., and Martin, S. B. 2003. Stalking new disease in creeping bentgrass. Carolinas Green. Nov-Dec. 22-26.

24. Turgeon, A. J. 1999. Pages 49-108 in Turfgrass Management, 5th ed. Prentice Hall, Upper Saddle River, NJ.

25. Uddin, W., J. Benelli, and Yenez, J. 2007. Evaluation of fungicides for control of Pythium foliar blight in perennial ryegrass. PDMR. 2:T042.

26. Vincelli, P., and Dixon, E. 2002. Resistance to QoI (QoI-like) fungicides in isolates of Pyricularia grisea from perennial ryegrass. Plant Dis. 86:235-240.

27. Wong, F. P., Midland, S. L., and de la Cerda, K. A. 2007. Occurrence and distribution of QoI resistant isolates of Colletotrichum cereale from annual bluegrass in California. Plant Dis. 91:1536-1546.

28. Wong, F. P, and Wilcox, F. W. 2001. Comparative physical modes of action of azoxystrobin, mancozeb, and metalaxyl against Plasmopara viticola (grapevine downy mildew). Plant Dis. 85:649-656. 